\title{
The Political Economy of the Flow of Information
}

\author{
Yantao $\mathrm{Bi}^{1}$ \\ ${ }^{1}$ School of Humanities and Communication, Hainan University, China \\ Correspondence: Yantao Bi, School of Humanities and Communication, Hainan University, 58 Renmin Avenue, \\ Haikou 570228, China. E-mail: bytaishan@sina.com
}

Received: January 9, 2012 Accepted: February 23, 2012 Online Published: July 1, 2012

doi:10.5539/ach.v4n2p43 URL: http://dx.doi.org/10.5539/ach.v4n2p43

\begin{abstract}
In the global context, the economic-technological powers are also the political-cultural powers, which have the capacity to obtain the maximising benefits from the global flow of information. Meanwhile, the countries which are inferior in economics, technology, etc. feel unable to enjoy the fruits of the information society; they have to struggle for their right to communicate.
\end{abstract}

Keywords: political economy, flow of information, global powers, cultural imperialism

\section{Introduction}

Marx and Engels once wrote, "In any epoch the ruling ideas are those of the ruling class, i.e. the class which is the ruling material force is at the same time its ruling intellectual force" (quoted in Inglis: 78). I strongly believe this principle not only applies nationally but also internationally. In the global context, the economic-technological powers are also the political-cultural powers, which have the capacity to obtain the maximising benefits from the global flow of information. Meanwhile, the countries which are inferior in economics, technology, etc. feel unable to enjoy the fruits of the information society; they have to struggle for their right to communicate. In this essay, I'll discuss why and how the world powers dominate the global flow of information, and how the dominance affects the world media and cultural production.

\section{Powers Are Powers}

Mowlana (1996:72) proposed that dimensions of power can be viewed in two categories of resources: tangible and intangible; the former include economics, technology, politics, cultural products, educational products and military hardware, while the latter are belief and value systems, ideology and religion.

This strategy, seeing power as Integrated Whole, provides a new forceful insight into the international relations and information flow. From this perspective, the control over the base value and information flow constitutes an unprecedentedly important power, a power to affect and reshape the world.

Mowlana's integrated approach was put forward in 1986, but in fact in 1985, the French sociologist Pierre Bourdieu proposed that "The social position of social actors is not only determined by economic capital, but also by their cultural, social and symbolic capital" (quoted in Hamelink, 1999). To this list of capital, Hamelink should add "information capital", by which he refers to the financial, technological and intellectual capital to handle the networks and the information flow, and also the motivation and ability to actively search and apply information (ibid).

At information age, the intangible resources of power are more important, and in most measure, the symbolic forms of products outweigh their material forms. It's the case even with the financial market as money has become a commodity in its own right. Meanwhile, the limitations and impracticality of a pure military model has been observed, as it is possible to win a war militarily and at the same time lose it politically (Mowlana, 1996: 81). This symbolises that today control of the political environment is a key factor to diffuse power globally. And that is why the international powers in the economic and political arenas are emphasizing symbolic exchange by promoting their values, preferences and tastes.

It is seen that the global economic and technological powers are more likely to become the political and cultural powers, which have louder voices in setting the global agendas. A case in point is that the authors of UNESCO 
report One World, Many Voices published in 1980 had to revise and re-revise the report under the pressure of the USA-led Western powers.

From the viewpoint of the developing countries, the control of the powers over the global flow of information has produced some negative influence, such as one-way communication, cultural imperialism, interference with domestic affairs, and so on.

\section{One-way Communication}

Some NWICO protagonists hold the belief that the international information system has increased, rather than decreased, the world inequality, with serious implications for the countries of the South. The pertinent ideas have been spelled out by Mustapha Masmoudi as follows:

- Owing to the socio-technological imbalance there was a one-way flow of informationfrom the "centre" to the "periphery", which created a wide gap between the "haves" and the "have nots";

- The information rich were in a position to dictate terms to the information poor, thus creating a structure of dependency with widespread economic, political and social ramification for the poor societies;

- This vertical flow (as opposed to a desirable horizontal flow of global information) was dominated by the Western-based international corporations;

- Information was treated by the transnational media as a "commodity" and subjected to the rules of the market;

- The entire information and communication order was a part of and in turn propped up international inequality that created and sustained mechanisms of neo-colonialism.

(quoted in Thussu, 2000: 44)

Mayjor negative effects of one-way communication on the developing countries can be summarised as follows:

Firstly, "The Western media gave an exploitative and distorted view of their countries to the rest of the world" (Thussu: 43). The Western media seem to be more interested in the dark side of the developing countries, and the coverage is far from sufficient and balanced. This has tremendously contributed to some misunderstanding and distorted images of the developing countries, which will in turn obstruct their development. Soon after I arrived in England, I have realised that some Europeans are holding so many misconceptions about China. And my experiences show that these misunderstandings are in most part caused by one-way communication. Undoubtedly, how to improve China's image on the international stage remains a hard nut for China to crack.

Secondly, one-way communication promotes Western values and beliefs to the developing countries, and in some cases threatens the national stability or even incites political upheavals in the developing countries, which I will expound later in this essay.

Thirdly, one-way communication adds more difficulties to the economic development of the developing countries. For many developing countries, the quantitative imbalance of information flow contributes to the unfavourable trade balance. Also, lack of information about and unfamiliarity with the outside world prevents them from further development.

Of course, some scholars, mostly from the First World, wouldn't admit the existence of one-way communication. Some even argue that the traditional division of the world into the developing countries and developed countries, into East and West, North and South, into First, Second, Third and Fourth World, into centres, peripheries and semi-peripheries no longer rings true (Tehranian, 1994; quoted in Vincent et al, 1999: 24). But from the standpoint of the developing countries, this new ideology simply reflects that some scholars are either too optimistic about the world future or blind to the widening gap between the developing countries and the developed ones, or they are trying to curtain the unpleasant reality the whole world is confronting.

\section{Cultural Imperialism}

One-way communication is closely related with the cultural dominance of some elite countries over the world, which has been termed as cultural imperialism.

In the words of Schiller (1976), cultural imperialism is the sum of processes by which a society is brought into the modern world system and how its dominating stratum is attracted, pressured, forced and sometimes even bribed into shaping social institutions to correspond to, or even promote, the values and structures of the dominating centre of the system (quoted in Golding and Harris: 49). 
On surface, cultural imperialism is only the cultural process which attempts to assure the ready acceptance and adoption of mediated cultural products which come abroad, but in reality, cultural imperialism is always intertwined with economic aggression or even political control. The interrelationship between them has been illustrated by Petras (1993: 6): "United States cultural imperialism has two major goals, one economic and the other political: to capture markets for its cultural commodities and to establish hegemony by shaping popular consciousness" (ibid: 6).

It seems undeniable that international communication acts as a reliable pioneer of cultural imperialism. The international information, originated from the international news media networks, has been geared to Western economic and political interests and projecting their version of reality through these global networks to the rest of the world.

In fact, one purpose of international communication has already been articulated by Al Gore, "Every link we create strengthens the bonds of liberty and democracy around the world" (quoted in Abramson and Ambrosi, 1998).

\section{National Stability and Security}

The superiority of the developed countries in "information capital" not only strengthens and maintains their status quo, but also in some senses threatens the national stability of the developing countries.

\subsection{Political Upheavals}

The MacBride Commission "charged that under the guise of the free flow of information, some governments and transnational media had 'on occasion tried to undermine internal stability in other countries, violating their sovereity and disturbed national development" (quoted in Thussu: 46). Although the charge was violently attacked by the Western world, it has been the case in the real world. As far as I can see, the international communications can implement this function in the following ways:

First, international communication and media can work as the vehicle for cultivating public dissent against some governments. Sometimes, this purpose can be achieved by opening up a small public sphere inside or outside a country. For example, outside China, some anti-CCP (Chinese Communist Party) websites have been operating successfully, where some political or religious activists publicise their dissatisfaction, theorise new ideologies, flame new schemes, and so forth.

Second, inside or outside a country, international communication can work as an intermediate stage connecting the political alliances and other resources, enlisting more international support.

Third, exiled activists no longer wait for situations to change so that they can return home, but instead can propagandise to change conditions from outside the country, a deterritorialsation of politics (Sreberny-Mohammad, 1997: 226). This is true in the case of the exiled Dalai Lama government.

Fourth, the detailed reports of and continued comments on some political events happening in a country can create pressure upon the government in question. In terms of Hong Kong Article 23, some activists and parties have been trying to manipulate the international communication system in order to influence HK government.

Fifth, international communication is a reliable channel for activists inside a country to communicate with the outside, sometimes with the help of international organisations. It's especially easy in case the activists are supported by a powerful foreign country. For instance, when a community radio audience in Guatemala and community radios are being discriminated against by auctioning of broadcasting frequencies, the oppressed immediately released the news to the international world and gained some support from some human rights organisations (Note 1). Immediate communication is especially critical when someone is arrested, because according to Amnesty International, if someone is tortured it usually occurs in the first 24 hours after arrest (Note 2). It's reported that e-mail played a role in the overthrow of former Zairean dictator Mobutu Sese Seko and the rise to power of his successor President Laurent Kabila, who used e-mail to stay in touch with journalists and supporters worldwide (Note 2). The Mexican Zapalist rebels even sidestepped traditional media by sending out communiqués via the Internet (Note 2).

\subsection{National Security}

As Nye (1990) has observed, "traditional concepts of national security and power are now plagued with different and increased vulnerabilities, both tangible and intangible in nature" (quoted in Mowlana, 1996: 74).

One example is information security. The advanced international communication corporation seems to be able to obtain any targeted information. To the contrary, developing countries in particular are vulnerable to lack of 
access to and control over such technologies and the information resources they bear. Accordingly, in terms of both civil and military information systems, the developing countries are at greater risks than the developed countries.

\section{Gendered Perspective}

Due to some historical, social and cultural reasons, women are regarded by a multitude of people as secondary to men in the society, and are faced with certain difficulties to get more benefits from the information age. However, it is inspiring that as the world becomes more internationally mediated, some international organisations can exercise more influence on the policy-makers in a particular country, in many cases via international media and communication channels. For example, at an international conference Undarya (1997) depicted the problems in Mongolia from a gendered perspective, which helped raise the public consciousness:

As Mongolia opened its doors to the rest of the world, many of the Western low-budget movies and TV entertainment programs and commercial advertisements have rushed into the country. Many pornographic newspapers have emerged that feed upon the Western equivalents, night show[s] on TV convey a lot of violence and pornography and that is not being censored in any way. Private TV channels and even the states-owned ones don't have internal policies on commodification of female body [sic], programs fostering gender stereotypes, promotion of pornography and the like."

In fact, this is only part of the problems the female audience is suffering from. Some research has shown that the media portrayed women as sex objects, secondary to men, emotional, weak, housebound, victims of domestic violence and sexual abuse. Furthermore, in advertisements, the youthful and beautiful images of women are frequently used to sell a product. Admittedly, the unbalanced portrayal of women is a by-product of the pursuit of maximising profits.

In June 2002 the United Nations General Assembly assessed the progress made in implementing The Beijing Platform for Action of 1995. It noted that poverty, limited access, computer illiteracy and language barriers prevented some women's participation online (Note 3). It seems that women are unlikely to reap the fruits of new technologies, which in turn obstructs the improvement of women.

\section{The Right to Communicate}

We have to admit that different countries and individuals hold different status in this information society. The cry for equal access has contributed to the creation of "the right to communicate", which is believed by some as both a basic human right and the means by which all other rights are realized (Note 4). Article 19 of The General Assembly's Universal Declaration of Human Rights (1948) stipulates:

Everyone has the right to freedom of opinion and expression; this right includes freedom to hold opinions without interference and to seek, receive and impart information and ideas through any media and regardless of frontiers (Mueth, 2001).

In practice, it's necessary to stress that the right to communicate should include that all people can communicate via their chosen media, and that their communication is heeded by others (Note 4). But to say is always easier. To define the various dimensions of access (e.g. Who has access to what, and under what conditions?) (Note 5) is much easier than to tackle the barriers to access (economical, technological, cultural, etc.).

Personally, besides personal right to communicate, I am much concerned with the national right to communicate. It's the countries which are still struggling for food and shelter that most need to express their desires to the outside world, but the fact seems to be that only few countries which control the global flow of information have the capacity to decide what the world wants and how to satisfy them.

\section{Conclusion}

Make no mistake, the interrelatedness between the political economy of the flow of information and the societies as media-international audience is complex and profound, which has been articulated by the Uruguayan writer Eduardo Galeano: "television decides where, when and how soccer will be played" (quoted in Abramson and Ambrosi). The few countries which can direct the global flow of information have been reaping the fruits of information flow, and this in turn helps enhance their capacity to control the information flow. Meanwhile, most of the countries which don't have the power to control the global flow of information aren't entitled to the advantages of the information flow, and this in turn comparatively reduces their ability to affect the global flow of information. It has formed a vicious circle, adding difficulty to the realisation of the universal access to the global flow of information and the right to communicate. 


\section{References}

Abrumson, B. D., \& Ambrosi, A. (1998). Imagining the Right to Communicate. Retrieved from http://amsterdam.nettime.org/Lists-Archives/nettime-1-9807/ms00018.html

Birdshall, W. F. (1998). A Canadian Right to Communicate. Retrieved from http://www.usask.ca/library/gic/15/birdshall.html

Golding, P., \& Harris, P. (1997). Beyond Cultural Imperialism. SAGE Publications, Inc.

Hamelink, C. J. (1999). Languages and the right to communicate. Retrieved from http://www.wacc.org.uk/publications/md/md1999-4/hamelink.html

Inglis, F. (1990). Media Theory. Oxford UK \& Cambridge USA: Blackwell.

Mhd. Bathusha, Z. G. Women and Media in Malaysia. Retrieved from http://commposite.uqam.ca/videaz/docs/zobaen.html

Mowlana, H. (1996). Global Communication in Transition. SAGE Publications, Inc.

Mueth, P. (2001). Independent Media and the Right to Communicate. Retrieved from http://publici.ucimc.org/aug2001/082001_8.htm

Raboy, M. (ed) (2002). Global Media policy in the New Millennium. University of Luton Press

Shade, L. R. (2005). Using A Gender-based Analysis in Developing a Canadian Access Strategy: Background Report. Retrieved from http://commposite.uqam.ca/videaz/docs/leshen.html

Sreberny-Mohammad, A. et al. (eds) (1997). Media in Global Context. Arnold.

Tehranian, M. (1999). Where is the New World Order? At the End of History or a Clash of Civilisation?. In Vincent, C. R. et al (eds), Towards Equity in Global Communication-MacBride Update. Hampton Press, Inc.

Thussu, D. K. (2000). International Communication. Arnold Undarya, T. Gender and Media in Mongolia. Retrieved from http://commposite.uqam.ca/videaz/docs/tuunen.html

\section{Notes}

Note 1. Right to Communication is trampled and auctioned in Guatemala. http://www.wacc.org.uk/publications/action/247/Guatemala.html

Note 2. The right to Communicate - The Internet in Africa. http://fxi.org.za/Medialaw/communicate.htm

Note 3. Anon. Participation. http://consult.womenspace.ca/participation 3.html

Note 4. TASH Resolution on the Right to Communicate. http://www.tash.org/resolutions/res02communicate.htm

Note 5. Shade, L.R. Using A Gender-based Analysis in Developing A Canadian. Access Strategy: Background Report. http://commposite.uqam.ca/videaz/docs/leshen.html 